\title{
WALT WHITMAN AND THOMAS MANN
}

\section{ROBERT K. MARTIN}

THOMAS MANN'S ENCOUNTER with Walt Whitman came at a crucial time in the novelist's career. Mann's 1922 reading of Whitman in the Reisiger translation ${ }^{1}$ establishes the missing link between Betrachtungen eines Unpolitischen of 1918 and Von deutscher Republik of 1922 and contributes to the final form of Der Zauberberg (1924). Whitman helped point the way for the Lubeck patrician from a monarchical-aesthetic tradition to the republicanism of the Weimar years and enabled his ultimate resistance to National Socialism in Germany. His poems and essays on male friendship helped establish an alternate tradition for Mann, and thus made possible the resurrection of Hans Castorp as a counterweight to the collapse of Gustav von Aschenbach.

Mann had had some familiarity with the American poet prior to 1922 . A letter from August 1909 contrasts Wagner and Whitman with the regretful conclusion that Whitman is more influential for the younger generation than Wagner. Mann reports on a Parzifal in Bayreuth with enthusiasm, although he simultaneously explains that his sympathy for Wagner has declined of late. A few months later in January 1910, Mann refers to Whitman's "Indian Rousseauism" in a context that links Whitman to fashionable novelty and above all to Mann's brother Heinrich and his associations with France and with democracy. The return to Whitman in 1922 indicates a degree of reconciliation in that long-lasting sibling rivalry. Coming to Whitman meant in part embracing Heinrich and hence accepting both Paris and the feminine.

Mann greeted the new Whitman translation in 1922 with great enthusiasm. He was friendly with the translator during the years from 1919 to 1922 when Reisiger was enlarging his translation. Peter de Mendelssohn has called Reisiger one of Mann's "closest and dearest friends."2 Mann welcomed the publication of the two-volume edition by S. Fischer with an open letter published in the Frankfurter Zeitung of 16 April 1922, in which he claimed that the German public could never thank Reisiger enough for "this great, important, even holy gift." He called Reisiger's introduction "a small masterwork of love." Quite apart from Mann's desire to praise his friend, one can sense the real enthusiasm that underlies this text. For Mann, what is most important in Whitman is the idea of "humanity," an idea that has particular significance for the Germany of the 1920s. Mann assimilates Whitman's "democracy" into the German concept of "humanity" and announces that Goethe alone is no longer sufficient to fulfill the old dream, but that "a dash of Whitman" is needed. For Mann, Whitman and Goethe have sensuality in common, the "Calamus," and sympathy with the organic. ${ }^{3}$ 
Thus, Mann's Reisiger text joins two elements that would always be crucial to his understanding of Whitman: politics and sexuality. Whitman makes it possible for Mann to abandon his allegiance to the monarchy, but by joining Whitman and Goethe, to retain the sense of a German humanist tradition. Whitman has been freed, then, at least in part, from his "French" connotation. He has also provided a means of reconciliation with the physical world, including in particular an acceptance of a physically manifest male friendship. Whitman showed a way for that male sexuality to be relocated and revalued: it could now be situated as part of a democratic and humanist vision. This shift, one of the most difficult in Mann's career, involved a break with the German homosexual tradition from which Mann sprang.

An acknowledgment of Whitman's homosexuality was an important part of Reisiger's task in his translations and introduction. That Mann was fully aware of this significance is clear from the diary entries. For instance, the entry for 31 May 1919 reports a visit from Reisiger during which he read from his translations, along with which there were "conversations about Whitman's man-love [Männerliebe]." It may be only coincidence, but the same day's entry records Mann's decision to read from the Hippe chapter of Der Zauberberg at a forthcoming reading. While the Hans CastorpPribislav Hippe relationship owes nothing directly to Whitman, Mann's decision to use it in such a public way may well reflect a growing openness about sexuality. The Hippe chapter is in many ways the response to Der Tod in Venedig, since in the later work Mann no longer parodies the possibility of a Platonic Steigerung of the love of a beautiful boy; instead he makes it his central principle.

In the preceding years Mann had been much concerned with understanding his own homosexuality and the role it might play in his writing and in society. He was influenced above all by Hans Blüher, whose Die Rolle der Erotik in der männlichen Gesellschaft he read on its publication in 1919. Blüher represents what we may term the reactionary-pederastic strain in German gay thought, basing his views on male superiority, male comradeship in military and chivalrous groups, and the beauty of the (German) male body. His earlier works were devoted in particular to the Wandervögel, the German youth group which bears some similiarity to the American or English Boy Scouts and which provided a pederastic core for National Socialism. Mann reports on his reading of Blüher in 1919: "one-sided, but true." He goes on, "There remains for me personally no doubt that the Betrachtungen are also an expression of my sexual inversion."4 In other words, Mann appears to acknowledge the extent to which his own praise for a manly German culture reflects a conception of homosexuality as the defense of erotic bonds between heroic soldiers. This view, which links the German homosexuality of the early twentieth century to ancient Sparta more than to the Athens of Plato, would be counteracted by the example of 
Whitman, which permitted Mann to retain a central place for male love even while rejecting a concept of it as inherently militaristic and aristocratic.

The result of Mann's Whitman experience is evident in the essay Von deutscher Republik, first given as a lecture in October 1922. There are still clear signs of the influence of Blüher here, but now Whitman is used to counter them. Thus, Mann reports Blüher's view that "the political disposition of its believers [i.e., in the realm of male love] are usually nationalistic and militaristic," while in Whitman's view the love of comrades is fundamentally democratic and peaceful, acting toward the union of states as toward the union of individuals. ${ }^{5}$ Whitman provides for Mann the way out of the Romantic association of love with death. Mann will now see death as a means of conversion to life. Thanks to Whitman this would become the dominant theme of the novel then underway, Der Zauberberg. "It could be the subject of a Bildungsroman," Mann remarks coyly, "to show that the experience of death is in the end an experience of life, that it leads to men [Menschen]." Such a novel would show an ultimate breakthrough, a decision to pass beyond the world of aestheticism - the very world that had been the foundation of an older homosexual poetics - to the assumption of life duties [Lebensdienste].

Whitman as mediated by Reisiger allowed Mann to construct a different sexual identity. The effect of Whitman on Mann in these years is a striking illustration both of Whitman's enormous social power ${ }^{\star}$ and of the fluidity of sexual identity: Mann's homosexuality remains an almost meaningless concept until it is translated into a sense of self and world, first by the model of Blüher and then by that of Whitman.

As long as Mann was under the influence of Blüher, his conception of homosexuality, however much inspired by a sense of deep boyhood friendship, remained associated with virility, masculine privilege, and military strength. In this Mann was part of a Germanic tradition, one that still has its place today in certain celebrations of masculinity in gay male culture. It was this aristocratic, misogynistic tradition from which Whitman helped Mann to escape. Through Whitman, Mann came to accept the "feminine," whether located within or outside the self. Like the Whitman of "The Children of Adam," therefore, Mann uses the figure of the woman, in this case Mme Chauchat, as a sign of a reconciliation to the body, a new awareness of the wholeness of eros that transcends gender. By making love verbally to Mme Chauchat, Hans Castorp affirms his first, unrealized love, that for Pribislav Hippe.

Reisiger's introduction to his Whitman translations helped Mann see

\footnotetext{
*A similar pattern may be seen in Whitman's influence in England where it is mediated through Edward Carpenter to people such as E. M. Forster and D. H. Lawrence. The latter, like Mann, owed much of his concept of homosexuality to a Germanic-chivalric tradition.
} 
Whitman as complementary to a German Romantic tradition, specifically, in Reisiger's terms, to the Schiller of "An die Freude." But Whitman, unlike his German precursors, looks back not only to an older, mythic world, but also, in Reisiger's words, beyond "the Bacchic frenzy" to "an affirmation of all being and of the nobility of all earthly and natural bonds."6 For Reisiger it is in Whitman's celebration of male comradeship, deeper than but not opposed to the love of men for women, that "the waking dream of Eros" lives and unites the lonely individual to the eternal; it is this dream that will echo in Der Zauberberg and its story of Hans Castorp's dream of love and death.

Der Zauberberg, which had been first conceived as a "Davos-Novelle," was thus radically transformed, in large part through the ability of Whitman to reveal to Mann a way out of the Romantic obsession with death. Whitman, far from being hostile to that German tradition, was perceived by Mann as following on it but transforming it by returning it to life. Whitman's influence can be seen clearly in the two climactic chapters that conclude each volume. In the first, "Walpurgisnacht," as Joel Hunt has shown, Mann makes use of Whitman's "I Sing the Body Electric" for Hans Castorp's anatomical love-making to Mme Chauchat. Mann has already called attention to this poem in Von deutscher Republik, where he terms the ninth section "an anatomical hymn, a piously orgiastic celebration of the human body." " At the end of his first seven months on the mountain, Hans uses Whitman's catalogue of the parts of the body to affirm life in the face of death. Hans and Mme Chauchat speak French in this section; perhaps this allows them a certain distance from their emotions, but it also amounts to a sign of Mann's reconciliation with France, the France that had represented for him the soft, feminine, and civilized, the world denounced in the Betrachtungen. ${ }^{8}$ But Mme Chauchat, whose very name involves an obscene French pun, is the source of spiritual arousal for Hans Castorp, an awakening he had known once before with Pribislav Hippe. The Hippe story, however, is fully inscribed in a Romantic context with blue flowers alongside a mountain stream, like a dream vision, disembodied except for the shavings of the pencil preciously preserved in Hans's desk. That ironically portrayed romance is then given form in the terms borrowed from Whitman. Clawdia Chauchat becomes an embodied Pribislav Hippe, as love is located in the physical world.

Mann had been fascinated by the idea of an ascending love (in terms derived from Plato) since at least the time of Der Tod in Venedig. But in that earlier work of 1913 the potential of physical love to act as a means to a higher, more spiritual love was not realized. Mann was too troubled by the loss of self implicit in Aschenbach's passion, by the danger to life and art of giving in to the Dionysian, to allow for a full celebration of the spiritual potential of physical love. But Whitman changed that, enabling Mann to speak, like Whitman, as a poet of the body as well as of the soul. Pribislav Hippe, like Tadzio Slavic and Dionysus, is reborn as Clawdia Chauchat, and Hans 
Castorp can, in the Carnival atmosphere of Walpurgisnacht, acknowledge his own love. The spiritual ascent, or Steigerung, that is at the heart of Der Zauberberg comes renewed from Whitman, from a recognition of the interdependence of what Hans Castorp calls "le corps, l'amour, la mort." Thus, the sensuality of "Walpurgisnacht" cannot be enough, any more than it is in Faust, but it can be a form of something higher, prefiguring another love to which it stands as the X-ray to the living form of Mme Chauchat. This recognition comes, for instance, from "Crossing Brooklyn Ferry," with its acknowledgment of the physical as a "necessary film" for the spiritual, and its moment of truth, "That I was I knew was of my body, and what I should be I knew I should be of my body."

Hans Castorp comes to acknowledge what Settembrini scornfully terms his "weakness for the Asiatic" (p. 618). Mann's understanding of Whitman, including his view of Whitman as the exponent of a different form of homosexuality, one that is not divorced from society or consecrated to the worship of power, made it possible for him to imagine a hero who could embrace his "other" side: call it feminine, French, Slavic, Southern, or dark. Hans rejects Settembrini's call for action against his "rival" as one based on a false notion of masculinity, one that is only "social-manly" [gesellschaftlichmännlich], as Castorp sees it. He has grown beyond chivalry. In his vision in the snow he learns that only love, and not reason, is stronger than death. This was the word he had sought when Hippe had appeared to him but he had not fully understood it. "For the sake of goodness and love man must allow death no dominion over his thoughts" (p. 523). Mann's rejection of death here is a repudiation of the Romantic-homosexual tradition he had inherited, one that regularly praised a love that was denied physical existence. In "Snow" Hans Castorp comes close to death, but it is precisely by this passage to death that he gains the strength to overcome it. The snow's call is that of nothingness, like that of "Der Lindenbaum" caught up with a deep eroticism, but finally refused for life and love.

The final section of Der Zauberberg, in which Hans Castorp is seen one last time, on the battlefields of World War I, is directly indebted to Whitman. Mann's reading of Whitman had brought him from the aristocratic to the democratic, from disgust at the body to celebration of the body. It had shown him there could be a homosexuality consistent with the highest ethical functions, that did not follow upon Blüher's proclamation that "Eros is the affirmation of a man independent of his worth."10 Mann bore witness to its meaning for him by portraying at the close of Der Zauberberg a possible resurrection out of death. On one side lie the bodies of two soldiers just killed: "they were friends, they had lain together in their need; now they were mingled and vanished" (p. 756). These slain young men embrace in death, and are assumed into the larger world. Meanwhile Hans Castorp lifts himself up and limps on, singing from "Der Lindenbaum." Mann closes with a question: "Out of this universal feast of death, out of this extremity of 
fever, kindling the rain-washed evening sky to a fiery glow, may it be that Love one day shall mount?" It is strikingly similar to Whitman's "Over the Carnage Rose Prophetic a Voice," with its affirmation: "Be not dishearten'd, affection shall solve the problems of freedom yet, / Those who love each other shall become invincible." Whitman's Civil War poems had particular meaning for Thomas Mann as he contemplated Europe's "civil war." Mann's traditional world had collapsed during that war, and many of his political and aesthetic values had been placed seriously in question. Perhaps more than the great modernists who were his contemporaries, Mann, as a German, had to confront the failure of traditional ideologies. If Der Zauberberg has something in common with that other great epic of the 1920s, Joyce's Ulysses, Mann does not share Joyce's sense of ultimate return to the comforts of home and wife. Hans Castorp is alone, an orphaned citizen of the new republic. Mann's reading of Whitman in 1922 made it possible for him to imagine a love that was based in the body and yet holy, that was fundamentally homosexual and yet moved through sexuality to social responsibility, that affirmed life rather than death. Although Mann would continue his inner debate with homosexuality all his life, he would never go back on the fundamental principles he had learned from Whitman, principles that freed him from aestheticism and worship of order and helped make him an implacable enemy of Nazism.

\section{Concordia University}

\section{NOTES}

1 Walt Whitmans Werk, ausgewählt, übertragen, und eingeleitet von Hans Reisiger, 2 Bände (Berlin: S. Fischer, 1922).

2 Thomas Mann, Tagebücher, 1918-1921, hrsg. Peter de Mendelssohn (Frankfurt/M: S. Fischer, 1979), 646.

3 Thomas Mann, Gesammelte Werke, 12 Bände (n.p.: S. Fischer Verlag, 1960), 10:626-627.

4 Mann, Tagebücher, 303.

5 Thomas Mann, Essays, Bd. 2: Politik, hrsg. Hermann Kurzke (Frankfurt/M: Fischer Taschenbuch Verlag, 1977), 90.

6 Walt Whitmans Werk, $1 \mathrm{xx}$.

7 Mann, Essays, 88.

8 See Joel Hunt, "The Stylistics of a Foreign Language: Thomas Mann's Use of French," Germanic Review, 32 (1957), 19-34.

9 Thomas Mann, Der Zauberberg (Frankfurt/M: Fischer Bücherei, 1967), 361. Other page references to this book will be noted parenthetically in the text.

10 Quoted in Claus Sommerhage, Eros and Poesis: Ueber das Erotische im Werke Thomas Manns (Bonn: Bouvier Verlag Herbert Grundmann, 1983), 116. 